\title{
Soybean production using growth stimulants
}

\author{
Ramis N. Saniev*, Alexey V. Vasin, N.V. Vasina, Anatoly N. Prosandeev, and Elena S. Makarova
}

Samara State Agrarian University, 446442 Kinel, Samara region, Russia

\begin{abstract}
The results of scientific research on the use of growth stimulators for the pre-sowing treatment of seeds and soybean crops in the forest-steppe zone of the Middle Volga are described. The results of 2016-2018 studies are presented. Plant safety indicators, photosynthetic activity and soybean yield for different treatment options are assessed. The use of two-component preparations increases soybean seedlings up to $58.5 \mathrm{pcs} / \mathrm{m} 2$. The maximum leaf area is formed when Risotorfin and Raikat Start are applied for the pre-sowing seed treatment. Due to the use of Raikat Start, the maximum grain harvest is $1.27 \mathrm{t} / \mathrm{ha}$ when treating crops with a microfertilizer mixture Megamix Profi in the 3-5 leaf phase + budding.
\end{abstract}

\section{Introduction}

At present, the problem of food production is one of the priorities for scientists. The practice of world agriculture showed that soy is one of the most productive crops; no plant can produce as much protein and fat 115-125 days as soy does $[1,2]$.

Soya can solve the protein problem. The need for soybeans is increasing against the backdrop of growing domestic demand for livestock and processed food products. Soya is a major technical crop. It is used in many industries (food, paint and varnish, chemical, textile, automotive, aviation, etc.). The lack of protein reduces productivity of animals, causes over-expenditure of feed by $30-45 \%$ and increases the production cost by 20 $28 \%$. [1, 3, 4].

The wide range of soybean applications is caused by its chemical composition - organic and inorganic substances, high-quality protein and energy. Soybean seeds contain $38-45 \%$ protein, which is two times more than in peas, $18-23 \%$ fat, $22-30 \%$ carbohydrates, $3-7 \%$ fiber, enzymes, vitamins, and minerals. A feature of soy protein is a high concentration of lysine. The limiting amino acid is methionine. Soybean seeds are rich in vitamins A, B1, B2, B3, B6, E, C, K. One kilogram of soy protein can replace $4-5 \mathrm{~kg}$ of meat. [1, 2, 5, 6].

Over the past decade, a lot of promising soybean varieties have appeared in the Volga region. They can be cultivated on irrigated and dry land. Productivity remains low due to the soil and climatic conditions of the main cultivation zones. The use of modern cultivation methods increases its productivity $[7,8]$.

One way to reduce the cost of agricultural products and increase gross indicators is to use a wide range of biologically active substances and micro-elements in a chelated form. It can increase productivity of plants, improve properties of seeds and their quality by using biologically active preparations for presowing seed treat- ment and spraying vegetative plants. These techniques make it possible to activate physiological processes during the vegetation, increase adaptive capabilities in adverse conditions, stabilize an increase in plant productivity and improve quality of the products $[1,9]$.

Photosynthesis is the main process forming organic compounds during which the electromagnetic energy transforms into the chemical one. Up to $90 \%$ of dry matter of plants is created; therefore, the crop yield is largely determined by the intensity of this process. As the leaf area increases, the share of absorbed energy increases as well. However, this pattern is observed when they increase only to certain sizes. Therefore, it is very important to create favorable conditions for the absorption and maximum use of solar energy, which can be an important means of increasing productivity. [5, 9-11].

\section{Materials and methods}

\subsection{Research objects}

The research objects are as follows:

Risotorfin (biofertilizer) is a preparation produced from nitrogen-fixing bacteria having a fungicidalstimulating effect for presowing treatment of legume seeds.

Raikat Start is a liquid organic fertilizer produced on the basis of an extract of marine algae and active amino acids, polysaccharides, cytokinins, balanced by the composition of macro- and microelements $\mathrm{N}-4 \%, \mathrm{P} 2 \mathrm{O} 5-8 \%$, $\mathrm{K} 2 \mathrm{O}-3 \%$, Fe- $0.1 \%, \mathrm{Zn}-02 \%, \mathrm{~B}-0.03 \%$ free amino acids, polysaccharides, cytokinins.

Kelix Mix is a liquid chelate used for eliminating micronutrient deficiencies $\mathrm{Fe}-5 \%, \mathrm{Mn}-2 \%, \mathrm{Zn}-0.37 \%, \mathrm{Cu}-$ $0.19 \%$, B- $0.65 \%, \mathrm{M}-0.18 \%$; the chelating agent is EDTA.

Aminokat is produced on the basis of an extract of seaweed. The plant growth stimulator increases the resistance of plants to adverse conditions (N-3\%, P2O5-

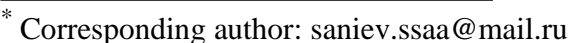


$1 \%$, $\mathrm{K} 2 \mathrm{O}-1 \%$, free amino acids $-30 \%$, including glutamic acid-7.2\%, lysine- $4.2 \%$, glycine- $3.6 \%$ ).

Raikat Development is a liquid organic-mineral fertilizer produced on the basis of an extract of seaweed and macro and trace elements, vitamins. A stimulant specially designed to improve the stage of development and growth of new plant tissues. N-6\%, P2O5-4\%, K2O-3\%, $\mathrm{Fe}-0.1 \%$, Mn- $0.07 \%$, Zn-0.02\%, B- $0.03 \%$, Cu- $0.01 \%$, Mo- $0.1 \%$, free amino acids- $4 \%$, seaweed extract - 5\%, cytokines $-0.05 \%$, vitamin complex $-0.2 \%$.

Megamix Profi is a mineral fertilizer for root and foliar top dressing with a high nitrogen content, as well as micro and macro elements. It provides nitrogen and microelement nutrition during the vegetation period. It compensates for increased nutritional needs in key development phases. N-6 g/l, Mg-15 g/l, S-29 g/l, Cu $=7$ $\mathrm{g} / \mathrm{l}, \mathrm{Zn}=14 \mathrm{~g} / \mathrm{l}, \mathrm{Fe}=3 \mathrm{~g} / \mathrm{l}, \mathrm{Mn}=3.5 \mathrm{~g} / \mathrm{l}, \mathrm{B}=1.7 \mathrm{~g} / \mathrm{l}, \mathrm{Mo}$ $=4.6 \mathrm{~g} / \mathrm{l}, \mathrm{Co}=1 \mathrm{~g} / \mathrm{l}, \mathrm{Cr}=0.3 \mathrm{~g} / \mathrm{l}, \mathrm{Se}=0.1 \mathrm{~g} / \mathrm{l}, \mathrm{Ni}=0.1$ $\mathrm{g} / \mathrm{l}$.

The purpose of the study is to increase soybean productivity in the forest-steppe of the Middle Volga region.

The objective is to assess plant safety, photosynthetic activity of plants (leaf area, photosynthetic potential, net productivity of photosynthesis), soybean yield depending on the use of various preparations for the seed treatment and vegetation.

\subsection{Research methods}

The 2016-2018 field experiment was conducted by the department "Crop production and land-cultivation." The soil of the experimental plot was ordinary carbonate, medium humus, medium-heavy, heavy loamy chernozem with easily hydrolyzable nitrogen (105-127 mg/kg), mobile phosphorus (130-152 mg/kg) and exchange potassium (311-324 mg/kg, PH 5.8). Humidification is natural.

The agricultural technology was traditional for the zone. Sowing was carried out with a AMAZONE D9-25 seeder at a seed rate of 750 thousand germinating seeds per 1 ha. Harvesting was carried out sublimely in the phase of full ripeness.

There are the following options of seed treatment: Risotorfin (strain 634b), Risotorfin (strain 634b), + Raikat Start 11 / t, Raikat Start 11/t (factor A); the options for treating crops with preparations are as follows: Control (without treatment), Kelix Mix $0.51 /$ ha, Aminokat + Raikat Development $0.51 /$ ha +0.5 1/ha, Megamix Profi $0.51 /$ ha . (factor B). The crops were treated twice in the phase of 3-5 leaves + budding.

The studies were carried out taking into account the field experiment methods developed by B.A. Dospekhov (1985) according to the guidelines for conducting field experiments with feed crops developed by the AllRussian Research Institute of Feed named after Williams (1987, 1997).

The weather conditions were special for soybeans. In April, precipitation in the amount of $68.3 \mathrm{~mm}$ at a rate of $27 \mathrm{~mm}$ replenished the moisture reserve, and the average daily temperature was $10.0{ }^{\circ} \mathrm{C}$ at a rate of $4.6{ }^{\circ} \mathrm{C}$. In May, the average air temperature was $20.30^{\circ} \mathrm{C}$, which is much higher than the average long-term indicators $\left(14.00{ }^{\circ} \mathrm{C}\right)$. The amount of precipitation was $28.3 \mathrm{~mm}$, which is slightly less than the long-term average data $33.0 \mathrm{~mm}$. In the first decade, the amount of precipitation was $5.1 \mathrm{~mm}$, in the second decade $-3.8 \mathrm{~mm}$, and in the third decade - $19.4 \mathrm{~mm}$. This suggests that favorable conditions were established during soybean sowing.

The intensive growth of biological aboveground soybean mass begins in June. Therefore, at this moment it is most susceptible to stress factors. In June, the average daily temperature was slightly below the normal one; precipitation was uneven throughout June, and amounted to $12.8 \mathrm{~mm}$ (the norm is $39 \mathrm{~mm}$ ).

July was characterized by sufficient moisture (the amount of precipitation was $55.2 \mathrm{~mm}$ ). The cool and humid weather was typical of the second and third decades. In August 2016, the average air temperature was $5.7^{\circ} \mathrm{C}$ higher than the annual average, but there was insufficient moisture; only $2.5 \mathrm{~mm}$ of precipitation fell in the third decade which is 16.3 times less than the norm.

In 2017, the weather conditions were different. May was favorable for sowing. In the second decade, when soybean was sown, $17.2 \mathrm{~mm}$ of precipitation fell, and the air temperature was $12.2^{\circ} \mathrm{C}$.

During the third decade, $51.3 \mathrm{~mm}$ of precipitation fell, which is much more than the mean annual value. During the period of seedlings and at the initial stages of plant development, the weather conditions were favorable.

June was unfavorable (waterlogged), since only $129.8 \mathrm{~mm}$ of precipitation fell over the whole month, and the air temperature was $3.4{ }^{\circ} \mathrm{C}$ below the normal one. This affected the growth and development of vegetative soybean plants. The growth rate of the aboveground mass was reduced.

In July, the amount of precipitation was almost 2 times lower than the average annual norm $(47 \mathrm{~mm}$.) In August, the plants lacked moisture, the average temperature was $21.4^{\circ} \mathrm{C}$.

In 2018, soybean was sown at the end of the second decade of May, the air temperature was $18.9^{\circ} \mathrm{C}$, which is $4.8^{\circ} \mathrm{C}$ more than the average annual value; in the first decade, the amount of precipitation was $6.7 \mathrm{~mm}$, in the third decade $-13.5 \mathrm{~mm}$.

In the first and second decades of June, the average daily temperature was 13.9 and $17.6{ }^{\circ} \mathrm{C}$; the development of plants was slowed down; only in the third decade, the temperature was higher than the average (23.9 ${ }^{\circ} \mathrm{C}$ ). During the first two decades, the amount of precipitation was $7.5 \mathrm{~mm}$ which is much lower than the norm; in the third decade, $11.2 \mathrm{~mm}$ of precipitation made it possible to compensate for the lack of moisture.

July was warm; the average temperature was $23,8^{\circ} \mathrm{C}$; the amount of precipitation was $10,6 \mathrm{~mm}$; in the second and third decades, the amount of precipitation was 31,3 and $30,8 \mathrm{~mm}$, respectively.

Thus, the weather conditions were not favorable for growing soybean. The limiting factors were the level of moisture and temperature (in 2017-2018) which determined the productivity of soybean crops. 


\section{Results}

Since soybeans are heat- and moisture-loving crops, a large amount of moisture is required for germination; therefore, dry conditions decreased germination [4]. When sowing seeds with high germination, the number of seedlings is always less than the number of seeds sown.

Table 1. The fullness of seedlings of soybean plants depending on the pre-sowing seed treatment in 2016-2018

\begin{tabular}{|c|c|c|c|c|c|}
\hline Seed treatment & Preparations & $\begin{array}{c}\text { Plant standing } \\
\text { density, pcs / } \\
\text { m2 }\end{array}$ & $\begin{array}{c}\text { Effect of } \\
\text { pre-sowing } \\
\text { seed treat- } \\
\text { ment }\end{array}$ & $\begin{array}{c}\text { Fullness } \\
\text { of } \\
\text { seedlings, } \\
\%\end{array}$ & $\begin{array}{c}\text { Influence of } \\
\text { pre-sowing } \\
\text { seed treat- } \\
\text { ment }\end{array}$ \\
\hline \multirow{4}{*}{ Risotorfin } & Control & 56.67 & \multirow{4}{*}{57.67} & 75.53 & \multirow{4}{*}{76.87} \\
\hline & Kelix Mix & 57.33 & & 76.40 & \\
\hline & Aminokat + Raikat Development & 58.00 & & 77.33 & \\
\hline & Megamix Profi & 58.67 & & 78.20 & \\
\hline \multirow{4}{*}{$\begin{array}{c}\text { Risotorfin }+ \text { Raikat } \\
\text { Start }\end{array}$} & Control & 57.00 & \multirow{4}{*}{58.50} & 76.00 & \multirow{4}{*}{77.97} \\
\hline & Kelix Mix & 58.67 & & 78.20 & \\
\hline & Aminokat + Raikat Development & 59.67 & & 79.50 & \\
\hline & Megamix Profi & 58.67 & & 78.17 & \\
\hline \multirow{4}{*}{ Raikat Start } & Control & 57.67 & \multirow{4}{*}{58.25} & 76.87 & \multirow{4}{*}{77.64} \\
\hline & Kelix Mix & 58.67 & & 78.20 & \\
\hline & Aminokat + Raikat Development & 58.00 & & 77.30 & \\
\hline & Megamix Profi & 58.67 & & 78.20 & \\
\hline
\end{tabular}

On average, for three years of research, the density was 56.67-58.50 pieces $/ \mathrm{m} 2$ with a full seedlings of $76.87 \% \ldots 77.97 \%$, the best preparation for seed treatment was Risotorfin + Raikat start (58.5 pcs./m2 $(77.97 \%)$ (Table 1). The use of two-component preparations contributed to better soybean germination.

The optimal sowing structure is one of the main factors for obtaining a high yield. The yield per unit area is determined by the number of plants and the mass of one plant. Safety of crops is the most important indicator.

Over the years of research, plant safety was high when using preparations for the pre-sowing seed treat- ment and vegetation treatment; the value for all options reached $60.52 \%$... 63.75\% (Table 2). The best option is application of Raikat Start and Megamix Profi (the safety was $63.75 \%$ ). The study of the influence of individual technological methods on the growth and development of agricultural crops is accompanied by observations of photosynthetic activity in crops. This issue is extremely important, since changes in plant growth conditions inevitably, directly or indirectly, affect the crop formation. The main indicators characterizing the production process are the leaf area, the photosynthetic potential and the net photosynthesis productivity.

Table 2. The number and safety of soybean plants for harvesting depending on the pre-sowing seed treatment and application of growth stimulants in 2016-2018.

\begin{tabular}{|c|c|c|c|}
\hline \multirow{3}{*}{ Seed treatment } & Preparations & $\begin{array}{c}\text { Number of } \\
\text { plants, thousand pcs / ha }\end{array}$ & Plant safety, $\%$ \\
\hline \multirow{3}{*}{ Risotorfin } & Control & 35.10 & 61.94 \\
\cline { 2 - 4 } & Kelix Mix & 35.60 & 62.10 \\
\cline { 2 - 4 } & Aminokat + Raikat Development & 35.60 & 61.38 \\
\cline { 2 - 4 } Risotorfin + Raikat & Megamix Profi & 35.63 & 60.73 \\
\cline { 2 - 4 } Start & Control & 35.90 & 62.98 \\
\cline { 2 - 4 } & Kelix Mix & 36.30 & 61.87 \\
\cline { 2 - 4 } & Aminokat + Raikat Development & 36.30 & 60.83 \\
\hline \multirow{3}{*}{\begin{tabular}{c} 
Raikat Start \\
\cline { 2 - 4 }
\end{tabular}} & Megamix Profi & 36.70 & 62.55 \\
\cline { 2 - 4 } & Control & 34.90 & 60.52 \\
\cline { 2 - 4 } & Kminokat + Raikat Development & 36.97 & 63.01 \\
\hline
\end{tabular}

Numerous studies by A.A. Nichiporovich and his colleagues have shown that plant productivity is closely related to growth and photosynthesis. The development of a photosynthetic apparatus is the first condition for increasing crop productivity. The second condition is development of a photosynthetic apparatus for increasing the leaf area (Kefeli V.I., 1991). The maximum leaf area is formed in the flowering phase. It is the best when applying Raikat Start for the seed treatment and a two- 
component solution Aminokat + Raikat Development or

Kelix Mix during the vegetation (Table 3).

Table 3. The area of soybean leaves depending on the pre-sowing treatment of seeds and application of preparations in 2016-2018, thousand $\mathrm{m}^{2} / \mathrm{ha}$

\begin{tabular}{|c|c|c|c|c|}
\hline \multirow{3}{*}{ Seed treatment } & Preparations & Bloom & Bean formation & $\begin{array}{c}\text { Green } \\
\text { ripeness }\end{array}$ \\
\hline \multirow{3}{*}{ Risotorfin } & Control & 43.6 & 35.2 & 24.3 \\
\cline { 2 - 5 } & Kelix Mix & 46.4 & 38.6 & 33.1 \\
\cline { 2 - 5 } & Aminokat + Raikat Development & 44.7 & 37.7 & 34.3 \\
\cline { 2 - 5 } & Megamix Profi & 45.6 & 37.8 & 35.3 \\
\hline \multirow{3}{*}{$\begin{array}{c}\text { Risotorfin + Raikat } \\
\text { Start }\end{array}$} & Control & 45.5 & 38.5 & 30.6 \\
\cline { 2 - 5 } & Kelix Mix & 44.6 & 39.7 & 32.1 \\
\cline { 2 - 5 } & Aminokat + Raikat Development & 44.3 & 41.3 & 36.2 \\
\hline \multirow{2}{*}{\begin{tabular}{c} 
Raikat Start \\
\cline { 2 - 5 }
\end{tabular}} & Megamix Profi & 44.8 & 43.1 & 36.3 \\
\cline { 2 - 5 } & Control & 44.3 & 34.4 & 31.8 \\
\cline { 2 - 5 } & Kelix Mix & 50.3 & 32.1 & 33.0 \\
\hline
\end{tabular}

By the phase of bean formation, the leaf area decreases, but still depends on the treatment options: in the option with Risotorfin and Kelix Mix, it is 38.6 thousand $\mathrm{m}^{2} /$ ha; with Risotorfin + Raikat Start and Megamix Profi - 43.1 thousand $\mathrm{m}^{2} / \mathrm{ha}$; with Raikat Start and Kelix Mix - 42.1 thousand $\mathrm{m}^{2} /$ ha.

In the phase of green ripeness, the level of leaf area decreases even more significantly and the largest leaf area is formed when Risotorfin + Raikat Start is used for the seed treatment and Aminokat + Raikat Development and Megamix Profi (36.2 and 36.3 thousand $\mathrm{m}^{2} / \mathrm{ha}$ ) are used for the crops treatment. The treatment of seeds with stimulants increases the photosynthetic potential of crops under the influence of stimulants on the photochemical activity of chloroplasts. The total AF value amounted to $2.128 \ldots 2.416 \mathrm{mln} . \mathrm{m}^{2} /$ ha days (table 4 ).

On average, over three years of research, the greatest photosynthetic potential was observed in the options with Raikat Start (2.416 mln.m2 / ha) and Kelix Mix.
Our studies revealed that soybeans differing in the photosynthetic potential do not show a high rate of accumulation of dry organic matter characterized by the net productivity of photosynthesis. In the initial period, the NPF was at the lowest level; but during the blooming, bean formation and green ripeness, this indicator was $3.783 \mathrm{~g} / \mathrm{m}^{2}$ per day (Table 5). Using Raikat Start for the pre-sowing treatment, the leaves work more productively when treating crops with Megamix Profi (net photosynthesis productivity is $3.033 \mathrm{~g} / \mathrm{m}^{2}$ ).

Treating plants had a positive effect on the soybean productivity. The yield was obtained when applying: Risotorfin $0.92 \mathrm{t} / \mathrm{ha}$, Risotorfin + Raikat Start $1.04 \mathrm{t} /$ ha. The use of Raikat Start ensure the crop yield of 1.09 t/ha. The maximum yield was obtained using Megamix Profi - $1.27 \mathrm{t} / \mathrm{ha}$. Thus, over the years of research, the maximum yield was achieved when Raikat Start is used for the pre-sowing treatment, and Megamix Profi - in the 3-5-leaf phase + budding.

Table 4. Photosynthetic potential of soybean depending on the pre-sowing seed treatment and application of preparations in 20162018 million, $\mathrm{m}^{2} /$ ha per day.

\begin{tabular}{|c|c|c|c|c|c|}
\hline \multirow[b]{2}{*}{ Seed treatment } & \multirow[b]{2}{*}{ Preparations } & \multicolumn{4}{|c|}{ Period } \\
\hline & & $\begin{array}{l}\text { Seedlings - } \\
\text { blooming }\end{array}$ & $\begin{array}{c}\text { Blooming - } \\
\text { bean formation }\end{array}$ & $\begin{array}{c}\text { Bean for- } \\
\text { mation - } \\
\text { green } \\
\text { ripeness }\end{array}$ & $\begin{array}{l}\text { For vege- } \\
\text { tation }\end{array}$ \\
\hline \multirow{4}{*}{ Risotorfin } & Control & 0.852 & 0.702 & 0.574 & 2.128 \\
\hline & Kelix Mix & 0.892 & 0.748 & 0.631 & 2.271 \\
\hline & Aminokat + Raikat Development & 0.870 & 0.727 & 0.642 & 2.239 \\
\hline & Megamix Profi & 0.888 & 0.727 & 0.651 & 2.266 \\
\hline \multirow{4}{*}{$\begin{array}{l}\text { Risotorfin }+ \\
\text { Raikat Start }\end{array}$} & Control & 0.884 & 0.725 & 0.572 & 2.181 \\
\hline & Kelix Mix & 0.865 & 0.736 & 0.626 & 2.227 \\
\hline & Aminokat + Raikat Development & 0.859 & 0.744 & 0.687 & 2.291 \\
\hline & Megamix Profi & 0.857 & 0.785 & 0.711 & 2.353 \\
\hline \multirow{4}{*}{ Raikat Start } & Control & 0.850 & 0.688 & 0.623 & 2.161 \\
\hline & Kelix Mix & 0.937 & 0.803 & 0.676 & 2.416 \\
\hline & Aminokat + Raikat Development & 0.970 & 0.780 & 0.612 & 2.362 \\
\hline & Megamix Profi & 0.844 & 0.684 & 0.620 & 2.148 \\
\hline
\end{tabular}


Table 5. Net soybean productivity depending on the pre-sowing treatment of seeds and application of growth stimulants in 2016$2018, \mathrm{~g} / \mathrm{m}^{2}$ per day

\begin{tabular}{|c|c|c|c|c|c|}
\hline \multirow[b]{2}{*}{$\begin{array}{c}\text { Seed } \\
\text { treatment }\end{array}$} & \multirow[b]{2}{*}{ Preparations } & \multicolumn{4}{|c|}{ Period } \\
\hline & & $\begin{array}{l}\text { Seedlings - } \\
\text { blooming }\end{array}$ & $\begin{array}{l}\text { Blooming - } \\
\text { bean formation }\end{array}$ & $\begin{array}{l}\text { Bean for- } \\
\text { mation - } \\
\text { green ripe- } \\
\text { ness }\end{array}$ & $\begin{array}{c}\text { For vege- } \\
\text { tation }\end{array}$ \\
\hline \multirow{4}{*}{ Risotorfin } & Control & 1.372 & 2.610 & 2.807 & 2.263 \\
\hline & Kelix Mix & 1.227 & 3.191 & 2.928 & 2.448 \\
\hline & Aminokat + Raikat Development & 1.487 & 2.790 & 3.182 & 2.486 \\
\hline & Megamix Profi & 1.880 & 3.424 & 2.743 & 2.682 \\
\hline \multirow{4}{*}{$\begin{array}{l}\text { Risotorfin + } \\
\text { Raikat Start }\end{array}$} & Control & 1.421 & 2.803 & 3.367 & 2.530 \\
\hline & Kelix Mix & 1.419 & 3.241 & 3.469 & 2.710 \\
\hline & Aminokat + Raikat Development & 1.941 & 3.715 & 3.339 & 2.998 \\
\hline & Megamix Profi & 1.770 & 3.086 & 3.208 & 2.688 \\
\hline \multirow{4}{*}{ Raikat Start } & Control & 1.395 & 3.316 & 3.435 & 2.715 \\
\hline & Kelix Mix & 1.236 & 3.022 & 3.783 & 2.680 \\
\hline & Aminokat + Raikat Development & 1.725 & 3.485 & 3.102 & 2.771 \\
\hline & Megamix Profi & 1.686 & 4.064 & 3.349 & 3.033 \\
\hline
\end{tabular}

Table 6. Soybean yield depending on pre-sowing treatment and application of growth stimulants for 2016 - 2018, t/ha

\begin{tabular}{|c|c|c|c|c|c|}
\hline \multirow{2}{*}{ Seed treatment } & \multirow{2}{*}{ Preparations } & \multicolumn{4}{|c|}{ per 1 ha } \\
\hline & & When $\mathrm{t}_{1}$ & ops & avera & \\
\hline \multirow{4}{*}{ Risotorfin } & Control & & & \multirow{4}{*}{0.92} & \\
\hline & Kelix Mix & & & & \\
\hline & Aminokat + Raikat Development & & & & \\
\hline & Megamix Profi & & & & \\
\hline \multirow{4}{*}{$\begin{array}{l}\text { Risotorfin + } \\
\text { Raikat Start }\end{array}$} & Control & & & \multirow{4}{*}{1.04} & \\
\hline & Kelix Mix & & & & \\
\hline & Aminokat + Raikat Development & & & & \\
\hline & Megamix Profi & & & & \\
\hline \multirow{4}{*}{ Raikat Start } & Control & & & \multirow{4}{*}{1.09} & \\
\hline & Kelix Mix & & & & \\
\hline & Aminokat + Raikat Development & & & & \\
\hline & Megamix Profi & & & & \\
\hline & & \multicolumn{2}{|c|}{201(} & 2017 & 2018 \\
\hline & & LSD об & 0.0 & 0.079 & 0.042 \\
\hline & & $\mathrm{LSD}_{\mathrm{A}}$ & 0.0 & 0.021 & 0.019 \\
\hline & & $\mathrm{LSD}_{\mathrm{B}}$ & 0.0 & 0.019 & 0.023 \\
\hline & & $\mathrm{LSD}_{\mathrm{C}}$ & 0.0 & 0.016 & 0.019 \\
\hline & & $\mathrm{LSD}_{\mathrm{AB}}$ & 0.0 & 0.042 & 0.033 \\
\hline & & $\mathrm{LSD}_{\mathrm{AC}}$ & 0.0 & 0.037 & 0.025 \\
\hline & & $\mathrm{LSD}_{\mathrm{BC}}$ & 0.0 & 0.033 & 0.027 \\
\hline
\end{tabular}

\section{Discussion}

In the forest-steppe of the Middle Volga region, treatment with Rizotorfin, $4 \mathrm{~kg} / \mathrm{t}+$ Raikat Start, 1 1/t should be followed by treatment with Megamix Profi. They ensure sufficient safety of plants under the moisture deficiency of $63.75 \%$.

The average leaf area is formed in the flowering phase, and significantly decreases by the green ripeness phase. The maximum photosynthetic potential is observed in the options with Raikat Start (2.416 mln. $\mathrm{m}^{2} / \mathrm{ha}$ ) for seed treatment and Kelix Mix for crops treatment.

\section{Conclusion}

Fertilizing plants during the growing season in the phase of 3-5 leaves + budding as well as seed treatment have a positive effect on the crop productivity; seed treatment with Raikat Start (1 1/t) and Megamix Profi increases the yiled up to $1.27 \mathrm{t} / \mathrm{ha}$ in the conditions of the Middle Volga region. 


\section{References}

1. V.P. Kazantsev, Agricultural Science of the EuroNorth-East 4(15), 20-23 (2009)

2. A.N. Osipchuk, In Scientific support of animal husbandry in Siberia In Materials of the II int. scientific and practical conf. 24-28 (Krasnoyarsk Research Institute of Animal Husbandry - Separate division of the "Federal Research Center" Krasnoyarsk Scientific Center of the Siberian Branch of the Russian Academy of Sciences, 2018)

3. A.S. Akulov, Legumes and Cereals 1(25), 36-40 (2018)

4. O.V. Syrmolot, Grain farm of Russia 5, 67-71 (2014)
5. A.B. Samsaliev, Bulletin of the Kyrgyz National Agrarian University named after K.I. Scryabin 2(47), 64-69 (2018)

6. G.G. Klasner, Int. Scientific and Practical Conf. World science. 1 5(21), 38-39 (2017)

7. T.A. Aseeva, Far Eastern Agrarian Bulletin 3(43), 917 (2017)

8. V.G. Vasin, Bulletin of Bryansk State Agricultural Academy 1, 42-48 (2010)

9. M.F. Fadeeva, Legumes and cereals 1(25), 40-42 (2018)

10. V.Yu. Frolov, Int. Scientific and Practical Conf. "World science" 1 5(9), 68-71 (2016)

11. A.A. Lysenko, Int. Scientific and Practical Conf. World science 1 8(12), 60-62 (2016) 